\title{
The Use of Learner Centered Techniques in the Teaching of English Language in Selected Secondary Schools of Lundazi District.
}

\author{
Friday Nyimbili ${ }^{1^{*}}$, Mubita Namuyamba ${ }^{2^{*}}$, Wanga, W. Chakanika ${ }^{3}$ \\ ${ }^{I}$ Phd student, University of Zambia, Lusaka, Zambia \\ ${ }^{2}$ Dept of Adult Education, University of Zambia, Lusaka, Zambia \\ ${ }^{3}$ Dept of Adult Education, University of Zambia, Lusaka, Zambia
}

*Corresponding Authors: Friday Nyimbili, Mubita Namuyamba, Zambia

\begin{abstract}
The teaching of English language in the secondary schools of Zambia is usually text based. Teachers graduate from different colleges and universities with diplomas and degrees and go to teach the secondary school learners. The purpose of this study was to assess the usage of learner centred techniques in the teaching of English language in the secondary schools of Lundazi district. The objectives of the study were to: establish how children were learning English using learner centred techniques and identify the challenges in using the learner centred activities in the secondary schools of Lundazi. The study used a mixed methods design and adopted concurrent triangulation on a population of 99 respondents. 72 respondents were pupils, 24 were teachers of English while 4 were heads of departments for languages in the secondary schools. Focus group discussions were used to collect data from 32 learners and 24 teachers while 39 answered a likert scaled questionnaire and 4 heads of departments were interviewed. Microsoft excel was used to analyse quantitative data while thematic analysis was used to analyse qualitative data. The findings revealed that teachers were not interested in teaching using learner centred techniques hence they used a limited number of learner centred activities. Despite this, pupils were interested in learning English using the learner centred activities. Challenges included inadequate teaching and learning material, over enrolment, rushing to cover the whole syllabus and teaching to make children pass examinations. The study recommended that teachers should use the continuing professional development meetings to share fully the process of teaching English language using learner centred techniques in the secondary schools. Government should control enrolment in secondary schools so that quality learning can be realized through teaching English using learner centred techniques.
\end{abstract}

Keywords: Learner centred techniques, teaching English, Lundazi District

\section{INTRODUCTION}

The traditional way of teaching was that teachers direct the learning process and students assume a receptive role in their education and learning process. With the advent of progressivism education in the 21 st century and the influence of some prominent psychologists, some educators have largely replaced traditional teaching methods which focused on how teachers taught instead of how pupils were taught, (Blumberg, 2008). Simasiku (2011) assets that learner centred learning is an approach to education which focuses on the needs of the learners so that they can get involved in the educational process. The learner centred paradigm departs from the traditional teaching methods (lecture methods) by focusing on learners more than teachers and the learning of the child more than the teaching by the teacher.

In this case, teaching techniques must allow for the active involvement and participation of learners in the learning process. Teachers should structure their classes to facilitate this active learner role. This will mean organising learners in smaller or larger groups, or pairs, or working with them individually (Rodgers and Richards, 1992). It will mean as well using teaching techniques that fit the purpose and content of the lesson and at the same time encourage active learner participation. This includes for example, explaining, demonstrating, posing questions, checking for understanding, helping, providing for active practice, and problem solving (MOE, 1992). Learner centred method acknowledges the importance of the learner in the teaching and learning process yet the instruction is broadened to 
include other activities that produce desirable learners' outcome. The government is advocating for learner centred approach of teaching yet there are a number of lapses which needs to be put in place like the teaching and learning material, enrolment levels and teacher familiarity with the method among others.

\section{OVERVIEW OF Literature}

By responding to the learner's needs, the ministry of education through the various policy guidelines on education realised the need for the transformation of the teaching methods from teacher centred to learner centred (MOE: 1977, 1996, 2000, 2013). The secondary school English language syllabus advocates for the use of learner centred techniques by teachers to teach English language in the secondary schools. The Zambian senior secondary English pupil's book has some units that contain a stage where the main activity is project work. This usually comes from a background of an extensive reading which gives the learners a hint of what they are supposed to do then they are asked to interview, find out from the community or develop some venture of knowledge construction.

The Zambian syllabus gives a guide regarding how teachers should teach in schools. The education policy does not emphasis the usage of a specific teaching method for teachers of English but they have to be resourceful, "the onus is on the teacher to find different methodologies for effective teaching. The activities would include individual work, pair work, group work, role playing of different situations and class presentations (MOE, 2012:06)."

The teaching of English in this context calls for the usage of different learner centred activities that shall make learners interact and use the language in practice sessions. The language policy again emphasizes that, "the teaching of English should be eclectic so as to include various approaches such as question and answer group work and class discussions (MOE, 2012:36)."

The new policy guideline is what guides the teaching and learning in Zambian schools. English in the secondary schools of Zambia is taught through text based approach coupled with communicative activities (MOE, 1996). The senior secondary English textbooks have specific activities which are learner centred as mentioned in the first quotation. A teacher of English for this reason is guided on the kind of activities learners will engage in at a given time. An instance is the teaching content for grade 10 English book one teacher's book. Every unit has more than two learner centred activities which include, debate, pair work, project, discussion and drama among others. These activities get complex as the learners ascend up in the education ladder to grade eleven and twelve. It is then important for a research to be conducted to investigate how the teachers are using such activities to teach English in class

Pham (2005) asserts that language learning is learning by doing. Language is skill which needs acquisition, perfection and practice. This process takes some time hence projects are supposed to be used on learners who have learnt the language for some time and have acquired sufficient skills to use. It is not very clear in the Zambian context how the teachers in schools are involving the learners in projects in the English classes.

The usage of learner centred activities in sub Saharan countries is not effectively implemented despite the governments documenting policies compelling teachers to use the approach, Eli (2013). Guthrie 2011, Tabulawa (1998) Mtika 2012), Brian and Chiphiko (2014) and Simasiku (2012) have all seen the need for African countries to change teaching and learning approaches with caution and not with donor funding. The Zambian curriculum and the senior English syllabus states that

The teaching and learning of English like other languages demand that pupils are actively involved in the learning process. This requires that a teacher chooses appropriate approaches, methods and techniques with a number of class activities that would facilitate learner involvement in the learning process. Teaching a language involves active participation in listening from the accurate speakers and using the words through practicing. Different researchers have highlighted a number of issues on how English should be taught in the different parts of the world and Zambia in particular.

Research by Lin (1999) in Taiwan proposed that teaching English was better done using learner centred activities in class. In this study, Lin sought to investigate the effectiveness of integrating a learner-centred blogging approach into English as a Foreign Language writing classroom in Taiwan. The researcher used a mixed method design to study a class of 18 students. Written tasks in English 
were given to learners, time after time, to assess their writing skills on line. The results suggested that the integration of learner-centred blogging into English as a Foreign Language (EFL) helped students develop writing skills as well as motivation and self-efficacy.

Another study observed that the teaching of English language using learner centred techniques makes learners to become social towards each other and interact for a beneficial purpose at various levels (Malekzadeh, Mustafa and Lahsasna, 2015). The findings were that learning a language such as information processing, communication processing, decision making processing and negotiation processing, were used by learners in the English class. The trio concluded that language learning for upper classes should include problem solving tasks coupled with group work

Teacher in most African schools and the sub Sahara in particular teach English to children for the sake of making them pass the national examinations. In a study conducted by Tabulawa (2008) in Botswana and number of challenges were found. Findings reflected that teachers used learner centred approaches to instruction to fostering critical thinking and problem solving skills in learners. Alas, learners were unable to apply the critical thinking learnt in class to apply to the situations in class because English was only used in class while outside class the learners used their indigenous language. This challenge was also reported by Vavrus and Bartlett (2015) in the study conducted in Tanzania where the challenges in effective learner centred implementation included lack of language practice by learners outside classroom. The teacher's role ended in class hence the learner's failure to speak the language outside was not the teacher's sole responsibility.

Learner centred teaching has failed in most countries due to a number of challenges which learners, teachers and the system itself faced. Schweinfurt (2011) warns that implementing the approaches has mostly failed in African countries because the pedagogy does not agree with the African norms and culture of its society. For example, a study on the implementation of leaner centred approaches in Namibia showed non implementation of the strategies citing challenges of teacher professional capacity, limited resources, cultural factors and learner background, (O'Sullivan, 2004). As this was not the only study, reporting on a study conducted among in-service teachers in South Africa, Brodie, Lelliot and Davis (2002) posit that the challenge with the implementation of learner centred approaches is that teachers tend to understand reform and implementation differently. Teachers never want to leave the class to be democratic but to conform to the teacher's dictatorial powers in class. Mtika and Gates (2010) also researching on learner centred approaches in Malawi conclude that appropriation and application of learner centred education is problematic. With such numerous challenges, it was not clear if the Zambian teachers were facing similar or more challenges in their teaching of English using the learner centred techniques in classrooms.

\section{AIM}

The purpose of the study was to assess the use of learner centred techniques in the teaching of English in Lundazi District of Zambia. The objectives were; establish how children were learning English using learner centred technique and identify the challenges in using the learner centred activities in secondary schools of Lundazi.

\section{Methodology}

The study used a mixed methods design and adopted concurrent triangulation on a population of 99 respondents. The sample size was 99 respondents. 71 respondents were pupils, 24 were teachers of English while 4 were heads of departments for languages in the secondary schools. Random sampling was used to select pupils and schools while purposive sampling was applied on teachers and heads of departments. Focus group discussions were used to collect data from 32 learners and 24 teachers while 39 answered a likert scaled questionnaire and 4 heads of departments were interviewed. Microsoft excel was used to analyse quantitative data while thematic analysis was used to analyse qualitative data.

\section{RESUlTS AND DISCUSSIONS}

\subsection{How Learners were Learning English Language in the Secondary Schools}

The findings in pie chart 1 above give a general impression that the majority of learners were interested in learning English using learner centred techniques with $69 \%$ who were interested against 
$28 \%$ who were said boring. The learners' interest in learning English using learner centred techniques was that $6(13 \%)$ it was very boring, $5(15 \%)$ respondents were of the idea that it was boring. 12 (31\%) respondents said were interested while $15(38 \%)$ said they were very interested in learning English using the learner centred techniques. The results meant that learners were motivated to learn English using learner centred techniques in the secondary school of Lundazi district.

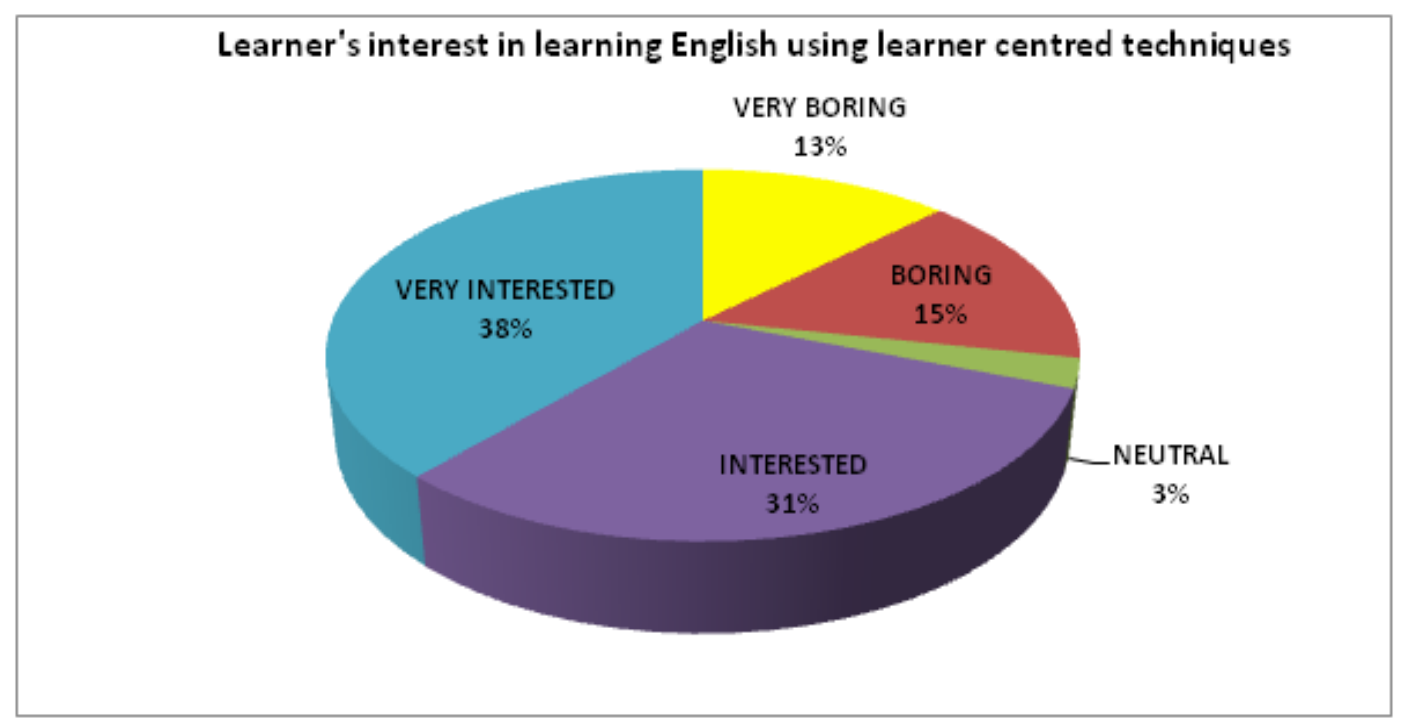

Figure1. Distribution of respondent's view on their interest in learning English using learner centred techniques

\subsubsection{Responses from the Focus Group Discussion with Pupils}

Findings from the learners revealed that teachers divided learners into groups when they wanted to involve them. This was done by turning desks to face each other. One respondent said, we choose ourselves and make our own groups because the teacher just says that make groups of six, six or five, five each. Another learner said, our teacher chooses anyone from the group to present the discussed work. If the presenter fails, the group is pinched. This was done to encourage everyone to concentrate. Further findings revealed that teachers used learner centred techniques when they were busy doing other things in class or school. One female learner said, my teachers of English only put us in groups when she was busy marking books for the previous exercise or when she wanted to pass time outside with friends. A male respondent added that, our teachers left work for us to discuss in groups and went outside telling stories with friends.

\subsubsection{Findings from Heads of Department}

The heads of departments used group discussions mainly when teaching learners. They divided the students into groups and gave them a topic to discuss. After the discussion, the learners presented their findings. One HOD mentioned that:

I usually involve my learners into my lesson by making them be in groups. I will first teach and explain a concept and after that I will break them into groups. I will give each group a task to work on and one member of the group will report to the class on their findings.

It was learnt that some learner activities which were schemed for various grades were not taught in English classes. One HOD pointed out:

I have not seen teachers teaching drama, field trips, project or involving them in outside learning activities. I usually put about four to five projects and field trips in the scheme but no one has ever come for permission to carry out these activities.

\subsubsection{Findings from Teachers}

Teachers mentioned that they used group work, presentations, debate and discussion to teach English language. One teacher said: I use debate to teach how to write an argumentative composition. Another teacher said: I use debate so that I prepare my pupils to be public speakers. As for the other techniques, I hardly use them. 


\subsubsection{Discussion}

This finding concur with Simasiku (2011) whose findings indicated that learners had interest in learning History using learner centred approach while teachers did not have the interest to teach History using the learner centred approach. The forgoing is contradicted by Zohrabi, Torabi and Baybourdiani (2012:19) who noted that: some students do not like to become the focus of attention and do classroom activities and instead prefer to stay in their more comfortable zone and simply be physically present but mentally inactive.Zohrabi, Torabi and Baybourdiani (2012) further established that learner centred approaches had a higher standard deviation of 4.999 while teacher centred approach had 4.119. The quantitative findings concur with this study that learners had interest in learning English language using the learner centred techniques. The only factor is to make teachers develop interest and have confidence that learners can do it with minimum supervision.

\subsection{Challenges in using Learner Centred Activities in Secondary Schools of Lundazi District}

\subsubsection{Responses from Heads of Department}

Amongst the many challenges, one male HOD mentioned that learner centred techniques in English classes only spark noise in class which disrupts the mood of learning. This was because the big groups usually argue from time to time without reaching an agreement. It was also recorded that the slow learners and those who did not speak English conversantly usually kept quiet as the extroverts dominated the conversations.

\subsubsection{Responses from Teachers}

One teacher highlighted that: my class has over 90 pupils those who come on a regular basis. They get too packed that desks cannot be moved, so I fail to move and supervise group activities.

Another female respondent revealed that: groups were not effectively monitored hence they sparked a lot of noise in class. The implications of these findings were that learners developed a negative attitude towards learning English using learner centred techniques.

\subsubsection{Responses from Pupils}

One student said; in our class we are more than 80, when the teacher makes groups, we overcrowd making contributions to the topic very difficult. Another female student noted that; when we are put in groups, I usually know that it is time to make noise for the naughty boys. I do not even waste time forcing myself to make a contribution. The teaching and learning material were also not sufficient for the class making the teachers to always use groups when teaching reading comprehension.

\subsubsection{Discussion}

Teachers and learners noted that the classes were over enrolled which made the learners make noise in groups and failed to respect the views of each other. The revelation coincides with Chiphiko and Shawa (2014) study which found that Malawian classrooms were overcrowded and this influenced teachers to avoid learner centred activities like group work which promoted meaningful interaction amongst learners. O'Sullivan (2004) and Bartlett (2015) concur that overcrowded classrooms prevented pupil interaction in the learning situation thereby defeating the purpose of learner centred teaching approach in African schools.

Further, the lack of adequate teaching and learning materials was a drawback to learner centred approach implementation in the Tanzanian schools as echoed by Vavrus and Bartlett (2015). Simasiku (2011) agrees that lack of teaching and learning materials such as books posed a challenge to the effective delivery of learner centred lessons in Zambian schools. Reading in pairs enables learners to scaffold each other as they strive to attain linguistic competence through purposive interaction which constructivism strives to achieve in a classroom.

\section{Conclusion}

The conclusions were drawn from the presented findings and discussion of the study on the teaching of English language using learner centred techniques in Lundazi district of Zambia.

Firstly, the findings revealed that teachers used group work and presentations to teach learners only when they were busy. The discussion authenticated this fact and further stated that teachers were not 
willing to teach learners using the learner centred techniques. This can be concluded that teachers were not following the government policy on education strictly to teach learners using the learner centred techniques. There was rigidness in teachers to welcome change in the pedagogical area of educational practice. This revelation also meant that learners were not learning the needed soft skills embedded in the learner centred techniques through the teachers in schools.

Secondly, the findings revealed that there was over enrolment in the secondary schools hence the teachers of English failed to supervise effectively the group discussions in the lesson. Indeed other scholars have echoed the over enrolment in most African countries to be the hindering factor to the effectively usage of learner centred techniques by the teachers. Perhaps this was the more reason teachers avoided complicated learner centred techniques like projects, drama and roles play. However, there was no justification as to why they did not follow the new policy on education and utilise the disadvantages to their advantage so that they teach the learners as the syllabus and schemes demands. This showed that the school authorities were not monitoring the teaching and learning effectively in the secondary schools of Lundazi district.

Lastly, the policy on education seems to be contradicting the reality on the ground regarding the teaching and learning. The policy demands that class enrolment is limited to 45 learners per class yet the reality is the opposite. Much needs to be done to harmonise the practices in the teaching of language with the given government policies in the Zambian secondary schools.

\section{RECOMMENDATIONS}

Recommendations were that teachers should use the CPD meetings to share fully the process of teaching English language using learner centred techniques in the secondary schools. This would make the teachers teach and impart the relevant skills which are enshrined in the experience of teaching English language using learner centred techniques. Lastly, government should standardize the enrolment of learners in class to the required 40-45 as the policy stipulate and monitoring should be enhanced by heads of department in the schools being quality controllers.

\section{REFERENCES}

[1] Blumberg, P. (2008). Implementing Learner Centred Approaches in your Teaching. Philadelphia: Longman.

[2] Brodie, K., Lelliot, A. and Davis, H. (2002). "Forms and Substance in Learner-Centred Teaching: Teachers" Take-Up From an In-Service Program in South Africa": Teaching and Teacher Education, 18:541-559.

[3] Chiphiko, E. and Shawa, L. B. (2014). "Implementing Learner-Centred Approaches to Instruction in Primary Schools in Malawi." November 2014. Mediterranean Journal of Social Sciences. 5(23): 256-287

[4] Eli, J. (2013). “The Student Centered Classroom.” Journal of Social Studies and History. 20(2):1-19.

[5] Lin, L. (1999). Supporting learning of variable control in a computer-based biology environment: Effects of prompting college students to reflect on their own thinking. Journal of research in science teaching, 36(7), 837-858

[6] Malekzadeh, M., Mustafa, M. B. and Lahsasna, A. (2015). "A Review of Emotion Regulation in Intelligent Tutoring Systems.” Educational Technology \& Society, 18 (4): 435-445.

[7] Ministry of Education, (1992). Focus on Learning. Lusaka: Government Printers.

[8] Ministry of Education. (1996). Educating Our Future: Policy on Education. Lusaka: Government Printers.

[9] Ministry of Education. (2013). Education Curriculum Framework 2013. Lusaka: Curriculum Development Centre

[10] Mtika, P. and Gates, P. (2010). "Developing Learner-Centred Education Among Secondary Trainee Teachers in Malawi: The Dilemma of Appropriation and Application." International Journal of Educational Development, 30: 396-404

[11] O'Sullivan, M. (2004). "The Reconceptualisation of Learner- Centred Approaches: A Namibian Case Study." International Journal of Educational Development, 24: 585-602.

[12] Richards, J. C. and Rodgers, T. (1992). Approaches and Methods in Language Teaching. (2 ${ }^{\text {nd }}$ Ed). New York: Cambridge University Press.

[13] Schweisfurth, M. (2011). "Learner-centred Education in Developing Country Contexts: From Solution to Problem?" International Journal of Educational Development, 31: 425-432. 
[14] Simasiku, L. (2011). The pupil's and Teacher's Perceptions of Learner centred Methods in the Teaching and Learning of History. (Unpublished Masters Dissertation, UNZA).

[15] Tabulawa, R.. (1997). "Pedagogical Classroom Practice and the Social Context: The Case of Botswana." International Journal of Educational Development, 17 (2): 189- 204

[16] Vavrus, F. and Bartlett, L. (2015). "Comparative Pedagogies and Epistemological Diversity: Social and Materials Contexts of Teaching in Tanzania." Comparative Education Review, 56 (4): 634-658.

[17] Zohrabi, M., Torabi, M. A. and Baybourdiani, P. (2012). "Teacher-centered and/or student-centered learning: English language in Iran.” English Language and Literature studies Journal, 2 (3): 18-30.

\section{AUTHORS' BIOGRAPHY}

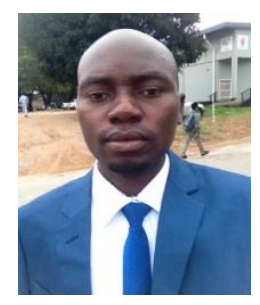

Nyimbili Friday is a teacher of English language and literature at Chikomeni day secondary school in Lundazi district and a part time lecturer at University of Africa. $\mathrm{He}$ is also a PhD student at the University of Zambia in Applied Linguistics. He also provides research consultation and he is a part time editor at Lusaland Investment.

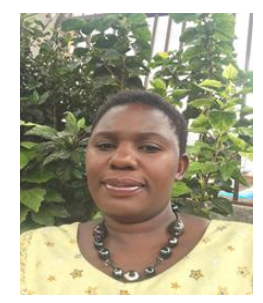

Namuyamba Mubita is a Part Time Lecturer and researcher in the Department of Adult Education and Extension Studies at the University of Zambia. She is also a Clinical Officer at UNZA Health Services. She also provides capacity building consultancy in various organizations.

Wanga, W. Chakanika is a Senior Lecturer and researcher in the Department of Adult Education and Extension Studies at the University of Zambia.

Citation: Friday Nyimbili, Mubita Namuyamba, Wanga, W. Chakanika. "The Use of Learner Centered Techniques in the Teaching of English Language in Selected Secondary Schools of Lundazi District". International Journal of Humanities Social Sciences and Education (IJHSSE), vol 5, no. 3, 2018, pp. 143-149 doi: http://dx.doi.org/10.20431/2349-0381.0503015.

Copyright: () 2018 Authors. This is an open-access article distributed under the terms of the Creative Commons Attribution License, which permits unrestricted use, distribution, and reproduction in any medium, provided the original author and source are credited. 